Newfoundland and Labrador Studies

\title{
Wayne Johnston. First Snow, Last Light. Toronto: Knopf \\ Canada, 2017. ISBN 978-0-73527-256-5
}

\section{Shoshannah Ganz}

Volume 33, numéro 1, 2018

URI : https://id.erudit.org/iderudit/1055874ar

DOI : https://doi.org/10.7202/1055874ar

Aller au sommaire du numéro

\section{Éditeur(s)}

Faculty of Arts, Memorial University

\section{ISSN}

1719-1726 (imprimé)

1715-1430 (numérique)

Découvrir la revue

Citer ce compte rendu

Ganz, S. (2018). Compte rendu de [Wayne Johnston. First Snow, Last Light. Toronto: Knopf Canada, 2017. ISBN 978-0-73527-256-5]. Newfoundland and Labrador Studies, 33(1). https://doi.org/10.7202/1055874ar d'utilisation que vous pouvez consulter en ligne. 
BOOK REVIEWS

Wayne Johnston. First Snow, Last Light. Toronto: Knopf Canada, 2017. ISBN 978-0-73527-256-5

Wayne Johnston's most recent novel is eminently readable. Well beyond the necessary ingredients of mystery, character, and plot, First Snow, Last Light contains many nearly perfect lines of prose worthy of pause and reverence.

The story begins in pre-Confederation Newfoundland and weaves its way through the familiar Johnston landscapes of Boston, New York, and back to the eve of Confederation in St. John's and the years that follow. In a novel rich in history, Johnston explores the rise of media mogul Ned Vatcher and his quest to solve the great mystery that creates and inspires both meaning and despair in his life. There are wonderful tidbits of Newfoundland lore - such as seventh sons of seventh sons and their power of prayer - and breathtaking views of desolation laced with almost unknown roads and vertigo-inducing impassable cliffs. In a particularly poignant passage, viewed from the small plane that Ned Vatcher flies, Johnston describes how "We followed the rampart-like headlands of the southwest coast, dipping into narrow fjords that snaked into the unknown core of Newfoundland. I saw brown herds of caribou that flowed to vanishing points like slow-moving streams, a jigsaw of groves of dark green spruce and purple birch and the intervening ice-caught lakes blown bare of snow by the ceaseless wind" (324).

The Newfoundland weather, tracked obsessively by more than one character, thaws and freezes, squalls and drenches, and through 
it all Sheilagh Fielding returns, as if from the dead, to hobble up and down the hilly scape of St. John's. To my mind, the return of this more-than-memorable character - indeed, an iconic Newfoundland character - is welcome. Sheilagh Fielding first appeared in The Colony of Unrequited Dreams (1998), told her own story in The Custodian of Paradise (2006), and reappears as a major character in the final work of the trilogy, First Snow, Last Light (2017). Fielding's dry wit and sarcasm remind the reader of the pleasures of the first reading journey with Sheilagh and the many other literary journeys with Johnston over the years. Johnston's love affair with language and the big brawling poor Catholic family of Ned Vatcher invites the reader into a relationship with Newfoundland's past. Even for veteran readers of Johnston, who may have lost interest in the rags-to-riches and rags again and riches again stories of wealth, power, and politics, this story has its own strange and tragic power. Never sermonizing, Johnston manages to subtly expose the history of mismanagement of Newfoundland's resources, and of the people who played a role in the downfall of Newfoundland as a nation. Johnston eulogizes the continued defeat of Newfoundland and Newfoundlanders, thus celebrating and mourning the Americanizing of Newfoundland and the very rags-to-riches stories his novels are based upon.

As long as you are not demanding or expecting an altogether new Johnston and are happy to revisit characters and landscapes from the past, First Snow, Last Light will get you through insomnia or perhaps even induce a little sleeplessness. I stayed up late to keep reading and I'm sure many others will likewise wish to indulge. I would caution that if you are trying to cut back on liquor or cigarettes this novel is literally laced with both, and like Mad Men will likely make you want to join the characters in a late-night nip of Scotch or bourbon.

Shoshannah Ganz Grenfell Campus, Memorial University of Newfoundland 